\title{
Towards Integrated Groundwater Management in China
}

\author{
Jie Liu and Chunmiao Zheng
}

\begin{abstract}
This chapter is intended to provide an overview of groundwater policy development in China, analyze the integration dimensions in current policy, identify the missing pieces and major challenges of integration in groundwater management, and offer suggestions towards more integrated groundwater management. The average groundwater recharge in China is about 880 billion $\mathrm{m}^{3} /$ year, $70 \%$ of which is unevenly distributed in the south. Groundwater exploitation has doubled over the past three decades, and agriculture is the largest consumer at approximately $60 \%$. The exploitation of groundwater sustains a steady increase in agricultural production, but also brings about a multitude of eco-environmental problems. Since the founding of the People's Republic of China, the focus of groundwater work has changed from investigating and exploiting to managing and protecting groundwater, and the viewpoint that groundwater is a single natural resource has gradually given way to that regarding groundwater as an environmental element with multiple functions. Integrated considerations of groundwater quantity, quality and its eco-environmental effects have been reflected in several programs aimed at prevention and control of groundwater contamination and land subsidence. Integration of surface water and groundwater by managed aquifer recharge and water transfer projects has been implemented. In the future, improvement of the legislation system, strengthening of institutional control, building-up of professional management teams, and increasing stakeholder involvement and
\end{abstract}

J. Liu

Center for Water Research, College of Engineering, Peking University, Beijing, China

C. Zheng $(\square)$

School of Environmental Science and Engineering, South University of Science and Technology of China, Shenzhen, China

Department of Geological Science, University of Alabama, Tuscaloosa, AL, USA

e-mail: czheng@ua.edu 
public participation are all needed facets towards a more integrated groundwater management.

\subsection{Introduction}

As an important part of water resources, groundwater plays an essential role in securing domestic uses, supporting socioeconomic development and maintaining ecological balance. Especially in the arid and semi-arid northern and northwestern parts of China with relative limited surface water, groundwater is non-substitutable. Indeed, China's groundwater situation is very grim (see also Chap. 2). Many areas are experiencing storage depletion with the water table continually declining, which further induces geologic hazards such as land subsidence, karst collapse and sea water intrusion; groundwater quality degradation and contamination is also becoming severe (Qiu 2010; Zheng et al. 2010). The conventional emphasis of groundwater management studies usually includes engineering and technological measures, modeling approaches (Demetriou and Punthakey 1999; Barthel et al. 2008; Liu et al. 2008; Shu et al. 2012; Cao et al. 2013; Qin et al. 2013), and economic leverage (Yang and Zehnder 2007; Zhang et al. 2008; Wang et al. 2010a). However, comprehensive studies that integrate legislative and administrative dimensions have often been ignored. To ensure that scientists understand what kinds of knowledge are required by policy makers and how hydrological expertise can be translated into real actions, it is essential to have an understanding of the current groundwater management system in China.

The objective of this chapter is to depict how groundwater policy has been progressively implemented in China, the existing gaps between the current and integrated groundwater policy, and possible steps towards more integrated groundwater management. The present state of China's groundwater resources is first described, and the historical groundwater development and management is then reviewed. This is followed by analysis of the integration dimensions in current groundwater policy and the existing major integration challenges. Finally, the authors offer suggestions towards more integrated groundwater management in China. Considering the size of the nation and the severity of the groundwater situation in China, this study not only has practical significance for improving China's groundwater development and management, but also can provide important implications for global groundwater governance. 


\subsection{State of China's Groundwater Resources}

\subsubsection{Types of Groundwater Resources and the Distribution}

Based on the occurrence of groundwater, China's aquifers can be divided into four major categories: (1) alluvial deposits in plains and basins; (2) groundwater in loess regions; (3) karstified limestone aquifers; and (4) bedrock aquifers in mountainous regions (Fig. 18.1).The first type is stored in porous and poorly consolidated sediments with an abundant amount of water, mainly distributed in alluvial plains, large river valleys, and the piedmont of inland basins. The total area is about 2.74 million $\mathrm{km}^{2}$ and provides groundwater around 168.6 billion $\mathrm{m}^{3} / \mathrm{year}$, accounting for $46 \%$ of the total exploitable groundwater. Groundwater in loess regions is a special type stored in unconsolidated sediments, mainly distributed in the loess plateau region in northern Shaanxi, southern Ningxia, western Shanxi and southeastern Gansu provinces. The total area is about 0.17 million $\mathrm{km}^{2}$, with the total exploitable groundwater in the amount of 9.7 billion $\mathrm{m}^{3} / \mathrm{year}$, about $3 \%$ of the nation's total exploitable groundwater. Karstified limestone aquifers occur in karst caves or fractures, with a total area of about 0.82 million $\mathrm{km}^{2}$. The total exploitable groundwater resource of this type is about 87 billion $\mathrm{m}^{3} / \mathrm{year}$, accounting for $24 \%$ of total exploitable groundwater resources. The bedrock aquifers mainly occur in the fractures of magmatic rocks, metamorphic rocks, and clastic rocks. The total area is about 5.75 million $\mathrm{km}^{2}$, with total exploitable groundwater in the amount of 97 billion $\mathrm{m}^{3} /$ year, accounting for $27 \%$ of the total exploitable groundwater resources (China's Groundwater Information Center 2014).

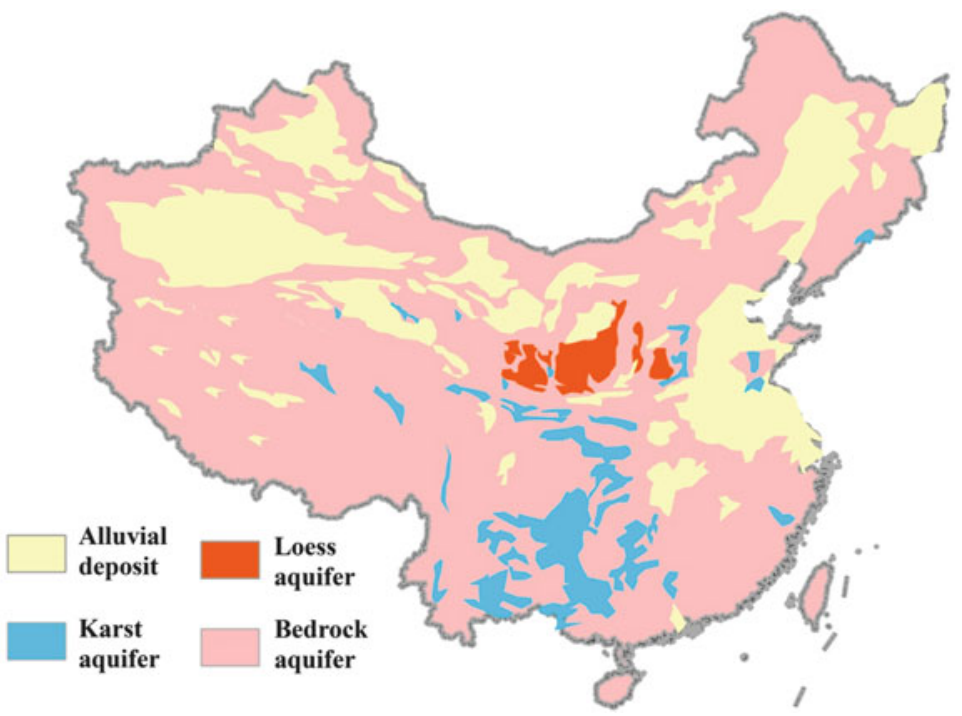

Fig. 18.1 China's major aquifer types and their spatial distribution 


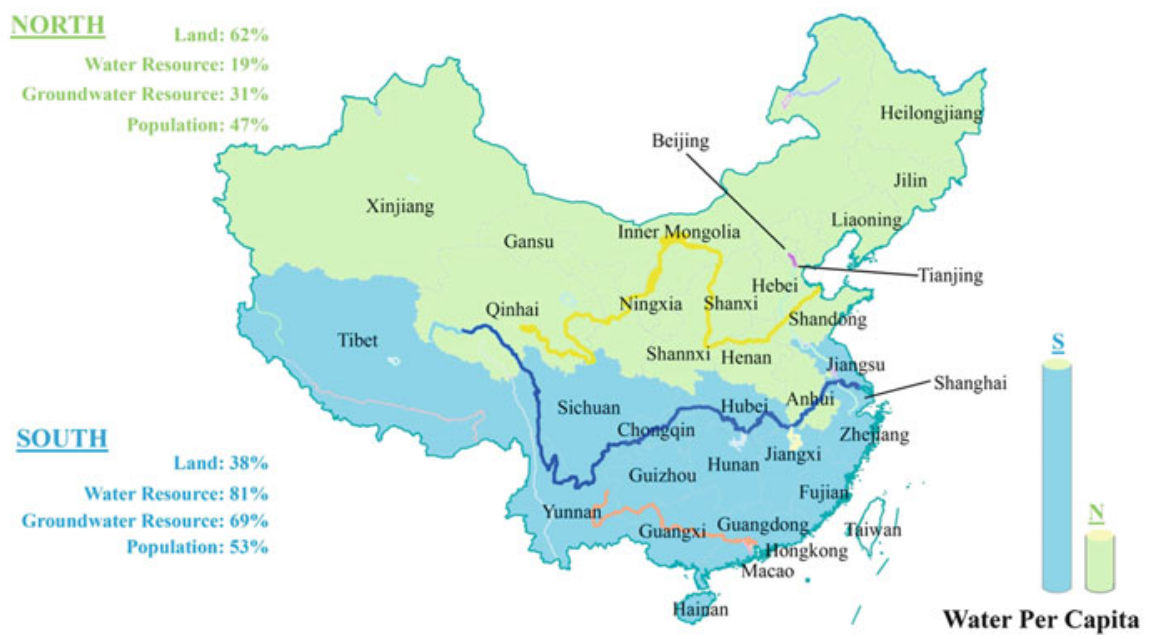

Fig. 18.2 Spatial distribution of groundwater resources in China (Data Source: The Ministry of Water Resources)

Table 18.1 Total amount and spatial distribution of China's groundwater resources $\left(10^{8} \mathrm{~m}^{3}\right)$

\begin{tabular}{l|l|l|l|l}
\hline Area & \multicolumn{2}{|l|}{ Total } & \multicolumn{2}{l}{ Exploitable } \\
\hline Nation-wide & 8837 & 3527 & \\
\hline North & 2743 & $31 \%$ & 1536 & $44 \%$ \\
\hline South & 6094 & $69 \%$ & 1991 & $56 \%$ \\
\hline & & & & \\
\hline Plain area & 2276 & $26 \%$ & 1561 & $44 \%$ \\
\hline Mountain area & 6561 & $74 \%$ & 1966 & $56 \%$ \\
\hline
\end{tabular}

According to the latest round (2000-2002) national groundwater resource assessment by the Ministry of Land and Resources, the average annual natural groundwater recharge in China is 884 billion $\mathrm{m}^{3} / \mathrm{year}$, accounting for nearly one-third of the nation's total water resources. The spatial distribution of groundwater resource in China is quite uneven. Nearly $70 \%$ of its groundwater resource is in southern China (38\% of the country's total land area) while only $30 \%$ is in northern China (62\% of the total land area). In general, the abundance of the groundwater resource decreases gradually from the southeast to the northwest (Fig. 18.2). Moreover, $74 \%$ of the groundwater resource is in the mountainous areas and $26 \%$ in plain areas, which adds difficulty and restriction in its exploitation and utilization (Table 18.1) (Zhang and Li 2004).

\subsubsection{Groundwater Exploitation and Overdraft Issues}

With fast economic development and population increase over the past three decades, groundwater exploitation in China has increased dramatically. Since the 


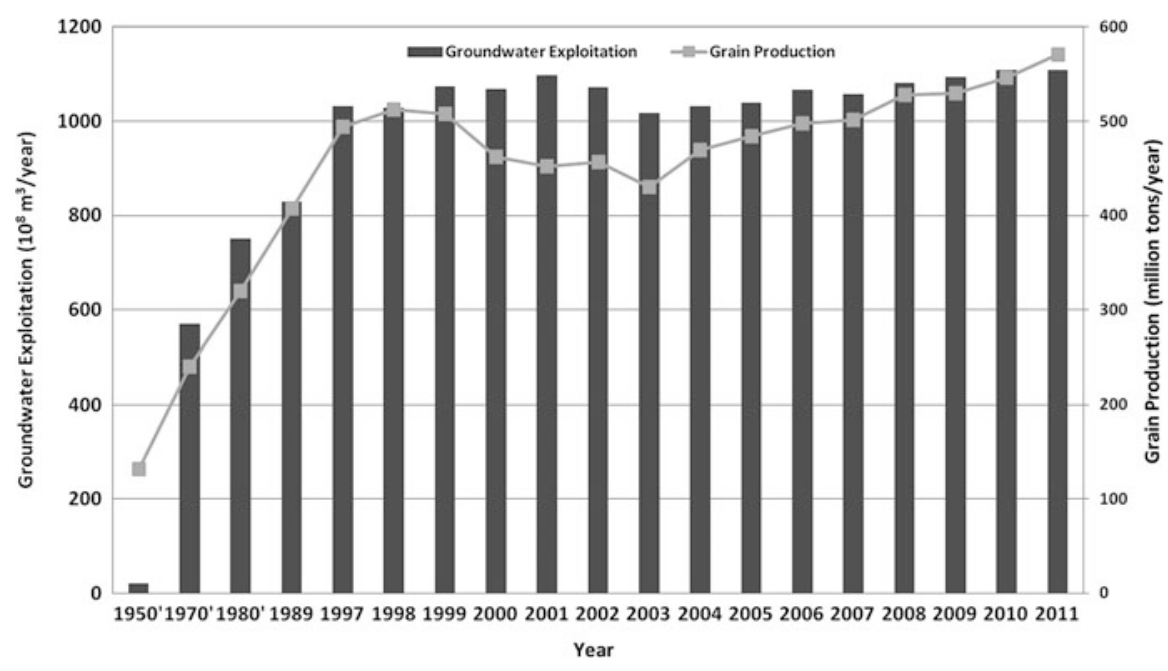

Fig. 18.3 Groundwater exploitation and total grain production from 1950s to 2011 in China (Data Source: The Ministry of Water Resources, China Statistical Yearbook)

1970s groundwater exploitation has grown at an average rate of 2.5 billion $\mathrm{m}^{3} /$ year. The total amount of groundwater exploitation was 57 billion $\mathrm{m}^{3} / \mathrm{year}$ in the $1970 \mathrm{~s}$, 75 billion $\mathrm{m}^{3} /$ year in the 1980s, and reached 111 billion $\mathrm{m}^{3}$ by 2011 , accounting for more than $18 \%$ of total water supply (Ministry of Water Resources 2011) (Fig. 18.3). Agricultural water use accounts for the largest percentage of the total groundwater use, although it has decreased from $88 \%$ in the 1980 s to $62 \%$ in the late 1990s; industrial and municipal water use has increased from $12 \%$ in the $1980 \mathrm{~s}$ to $38 \%$ in the late $1990 \mathrm{~s}$, and this trend will likely continue to keep pace with the acceleration of industrialization and urbanization.

Among the 657 cities in China, more than 400 (61\%) cities use groundwater as their major water supply. In rural areas of China, people generally use groundwater as their drinking water source, and $40 \%$ of the total farmland is irrigated by groundwater. In northern regions, $65 \%$ of domestic water, $50 \%$ of industrial water and $33 \%$ irrigated water come from groundwater (Ministry of Environment Protection 2011). The exploitation of groundwater has allowed a steady increase in grain production. Figure 18.3 shows the relationship between groundwater exploitation and total grain production in China from the 1950s to 2011. All those indicate that China's economic development and people's livelihoods depend greatly on groundwater.

With the increasing groundwater abstraction rate, most aquifers in northern China have been over-drafted, among which the entire Hebei Province, the aquifers in mega or middle-sized cities such as Beijing, Tianjin, Shenyang, Haerbin, Jinan, Taiyuan and Zhengzhou are all over-pumped. More than 100 regional groundwater cones of depression have been formed with total area exceeding $150,000 \mathrm{~km}^{2}$. In the North China Plain, the cone of depression has spanned from Hebei to Beijing, Tianjin, Shandong, with the groundwater level in an area of $70,000 \mathrm{~km}^{2}$ lower than 
sea level (Liu et al. 2001). The regional groundwater level decline has also impacted groundwater dependent ecosystems, such as the shrinking or disappearing of wetlands and degradation of vegetation coverage. Land subsidence occurred in more than 40 cities because of groundwater overdraft, among which Shanghai, Tianjin and Taiyuan have the maximum accumulative land subsidence over $2 \mathrm{~m}$. In coastal areas such as Dalian, Qinhuangdao, Cangzhou, Qingdao, and Beihai, sea water intrusion has caused degradation of groundwater quality in a total area of nearly $1000 \mathrm{~km}^{2}$, among which Shandong and Liaodong Peninsula are the most seriously affected. In addition, aquifer salinization has been caused by intensive irrigation in the North China Plain (Foster et al. 2004), the middle stream of the Yellow River and inland basins of northwestern China.

\subsubsection{Groundwater Quality Issues}

The overall quality of groundwater has deteriorated rapidly in recent years. According to the latest well sampling campaign in 2012 in nearly 200 cities and administrative regions by China's Ministry of Land and Resources, some $57.4 \%$ of over 4,900 samples indicated groundwater of category IV or V - on a scale of I-V from the best to poorest quality (Ministry of Environmental Protection 1994, 2012). The spatial information of groundwater quality is shown in Fig. 18.4, from which it can be seen that groundwater contamination in Taihu basin, Liaohe basin, Haihe basin and Huaihe basin is the most severe, with $91 \%, 85 \%, 76 \%$ and $68 \%$, respectively, of their total sampled areas with groundwater of category IV or V (Ministry of Environment Protection 2011).

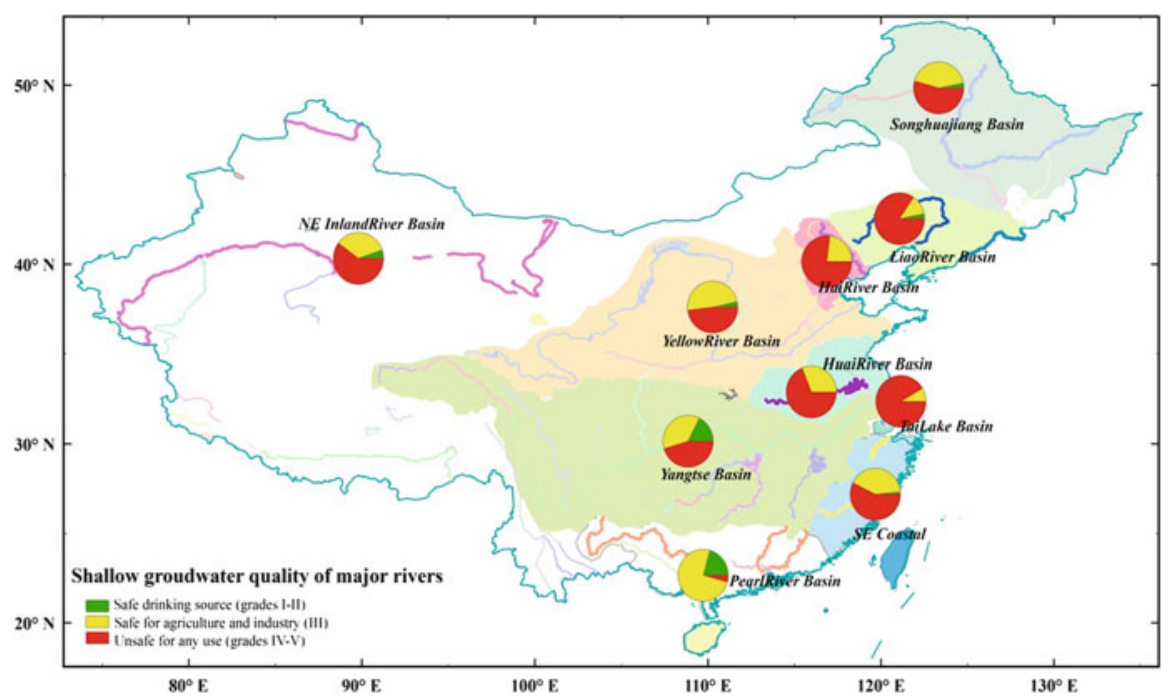

Fig. 18.4 Groundwater quality in major plains and basins of China. Categories I and II: good, category III: moderate, and categories IV and V: poor (Based on Tang et al. 2006) 
China Geological Survey conducted an investigation and assessment of groundwater contamination in the North China Plain from 2006 to 2011. Based on 7,451 groundwater samples, shallow aquifers show more serious contamination than deep aquifers. The major pollutants include nitrates, heavy metals, and toxic organic compounds. The nitrate pollutant has a planar distribution surrounding villages and cities, and the major sources include unregulated disposal of polluted water from industries, and the overuse of fertilizer in agricultural activities. $\mathrm{Pb}, \mathrm{Cr}$ and $\mathrm{As}$ are the major heavy metals with a high rate of exceeding environmental standards, and have a spotty or linear distribution pattern around cities and industries. The unregulated disposal of polluted water and poorly managed wastes are the major cause of heavy metal pollution. Toxic organic compounds have a low rate of exceeding standards but a high detection rate, mainly in shallow aquifers. The major source comes from the production, process, storage and use of those organic compounds by petrochemical industries (Zhang et al. 2012).

"It is estimated that 190 million Chinese fall ill and 60,000 die because of water pollution. According to the World Bank, such illnesses cost the government \$23 billion a year, or $1 \%$ of China's gross domestic product. And that doesn't factor in the impact on China's ecosystems and food supply" (Qiu 2011). The degradation of groundwater quality and groundwater contamination accidents also provokes sociopolitical unrest from the public. In the year of 2013, business owners in Shandong province were accused of disposing waste water through injection wells and contaminating shallow groundwater, which ignited a firestorm on the Internet (Zheng and Liu 2013).

\subsection{Historical Perspectives on Groundwater Development and Management in China}

China has a long history in utilizing groundwater resources. The earliest ancient well was found in Hemudu village of Yuyao, Zhejiang Province more than 5000 years ago (Liu 1987). Back to 2000 years ago, the Chinese began to use tube wells to exploit shallow groundwater. Systematic development of groundwater started after the founding of the People's Republic of China in 1949, and the development and management of groundwater in China has been closely related to the country's economic development. More than 60 years of groundwater development and management in China can be divided into the following five distinct stages (Ji and Wang 2009).

\subsubsection{9-1958: Initial Development}

China's hydrogeological work was launched right after the People's Republic of China was founded in 1949, closely linked with the demands of the nation's reconstruction and socioeconomic development. During this stage, groundwater 
was managed as a type of geological resource by the Ministry of Geology back then (later changed to the Ministry of Geology and Mineral Resources, and now the Ministry of Land and Resources). The major task of this stage was to conduct hydrogeological investigations for the major industrial and urban construction projects. In 1956, a regional hydrogeological investigation was initiated in the main basins, such as the Chaidamu Basin in Qinghai Province, the Hexi Corridor in Gansu Province and the Yangtze River basin. Groundwater protection was mentioned for the first time in the "Interim Regulations on Mineral Resources Protection" (1956), which states that: hydrogeological investigations and reasonable extraction plans should be enforced to prevent groundwater resources from being damaged; and the relevant departments should adopt effective measures to prevent groundwater contamination from the discharged industrial, medical or municipal wastewater. The discipline of Hydrogeology has been set up since 1952 in colleges, and academic activities have been carried out since the late 1950s. At this stage, many working methods were learnt and adopted from the former Soviet Union.

\subsubsection{9-1978: Growth Period}

Since 1959, hydrogeology has entered a growth period in China. Every province (autonomous region and municipality) built up their own hydrogeological and engineering geological teams. With the extensive development of agricultural activities and railway construction, hydrogeological investigations was conducted accordingly. Great progress was achieved in finding groundwater sources for areas with severe water shortage and endemic diseases. The academic and teaching activities also developed rapidly. In 1964, hydrogeological maps for the HuangHuai-Hai (which means the Yellow River, Huai River and Hai River in Chinese) Plain and the Song-Liao Plain (at a scale of 1:1,000,000) were completed. The national hydrogeologic maps were compiled by the Institute of Hydrogeology and Engineering Geology in the late 1970s, which integrated the previous hydrogeological investigations in different plains and basins. In 1977, a geological survey team for karst areas was formed, whose name was then changed to the Institute of Karst Geology in 1979. In 1962, land subsidence appearing in Shanghai led to the concerns over geo-environmental issues and the study of environmental geology as an important subject followed. Rational groundwater development and protection to prevent groundwater level decline, quality deterioration, land subsidence and collapse have been studied in many large and middle cities and the North China Plain since then.

\subsubsection{8-1998: Comprehensive Research and New Technologies}

In the 1980s comprehensive investigation and mapping of hydrogeological conditions started, based on natural geographical units. The major achievements 
include the hydrogeological maps of the Yangtze River Basin and the Yellow River Basin. By the mid-1980s, the first round of national groundwater resources assessment had been completed (Zhang and Li 2004). Following that, the groundwater resource assessment in the northern karst region was conducted. In 1996, the regional hydrogeological survey of the entire country was completed, with two-thirds of the national territory at the scale of 1:200,000 and the rest at the scale of 1:1,000,000. New concepts and technologies in hydrogeological research and practice from western developed countries were introduced to China during this period; and some technologies such as drilling and geophysical technologies were also actively developed in China as well.

In 1988, the first comprehensive national Water Law was enacted. Before then there was no systematic management structure and no specific regulations or laws for groundwater. The only regulation directly related to groundwater resources is the Interim Regulations on Mineral Resources Protection enacted in 1956. Following the Water Law, Regulations on Water Pollution Prevention and Control in Drinking Water Source Protection Area, and Regulations on Urban Groundwater Development and Management were formulated in 1989 and 1993, respectively. The Mineral Resources Law was amended in 1986, and the specific rules for the Implementation of the Mineral Resource Law were formulated in 1994 (Department of Water Resources 2008). During this stage, the Ministry of Construction was in charge of urban groundwater management; the Ministry of Land and Resources was responsible for groundwater investigations; and groundwater quality management was under the jurisdiction of the Ministry of Environmental Protection.

\subsubsection{9-2008: Large-Scale Land and Resources Survey and Assessment}

The second round of national groundwater resource and environmental assessment was conducted by the China Geology Survey (CGS) from 2000 to 2002. The CGS finished the regional hydrogeological survey in 11 major plains and basins in northern China (Fig. 18.5) and published a series of reports (Zhang and Li 2004). Groundwater recharge, runoff and discharge as well as their changes over the past 20 years were investigated. At the same time, geo-environmental issues related to groundwater such as land subsidence and seawater intrusion were also investigated comprehensively. A basin-scale digital groundwater information system was developed. Investigation of karst groundwater resources was conducted in eight provinces, including Yunnan, Guizhou, Guangxi, Hunan, Chongqing, Hubei, Guangdong, Sichuan, involving nearly 80 million people and a total area about 1 million $\mathrm{km}^{2}$.

From 2005 groundwater quality investigations and assessments were conducted in the eastern plains, including Zhujiang Delta, Yangtz Delta, Huaihe River Basin and the North China Plain. Questions such as the state of the nation's groundwater, how the groundwater quality evolves over time, and how natural factors and human activities impact the quality of groundwater were addressed. The groundwater pollution investigation in the Pearl River Delta, Yangtze River Delta, the plains 


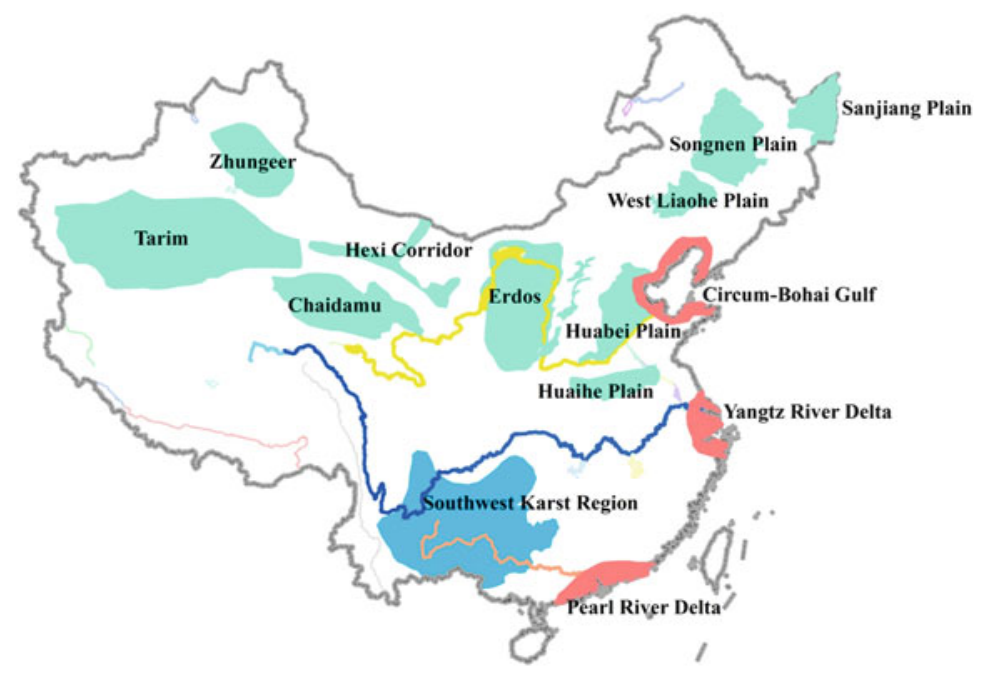

Fig. 18.5 Regional hydrogeological surveys in major plains conducted by China Geological Survey (Data Source: China Geological Survey)

area of the Huaihe Basin, the North China Plain, the lower Liaohe Plain and the eastern plain with an area of $430,000 \mathrm{~km}^{2}$ targeted inorganic to organic components. This provided important background information on groundwater quality for subsequent national groundwater pollution prevention and control efforts.

Groundwater exploration and exploitation in water-shortage and endemic areas was also been conducted. In the arid northwest region, and the so-called "red soil region" in the southwest, as well as areas with endemic diseases, the CGS carried out hydrogeological surveys and groundwater supply demonstration projects, and solved the drinking water supply problem for more than 20 million people.

The national monitoring network for the dynamic changes of groundwater level and quality has been under construction (Zhou et al. 2013). Currently, there are 24,417 groundwater monitoring stations, mainly distributed in the northern part of China. In the near future another 20,455 monitoring stations are planned to be constructed or reconstructed, which will cover $3,500,000 \mathrm{~km}^{2}$ and dynamically monitor the groundwater level and quality changes of major plains, basins, karst areas and ecologically vulnerable areas. Figure 18.6 shows the density of monitoring stations in each province of China (China Groundwater Information Center 2014).

\subsubsection{9-Present: Attempt at Integrated Water Management}

The integration dimensions of groundwater development and management have been considered to a greater extent during this stage. Back to 2000, the administrative management functions on groundwater resources of both the Ministry of 


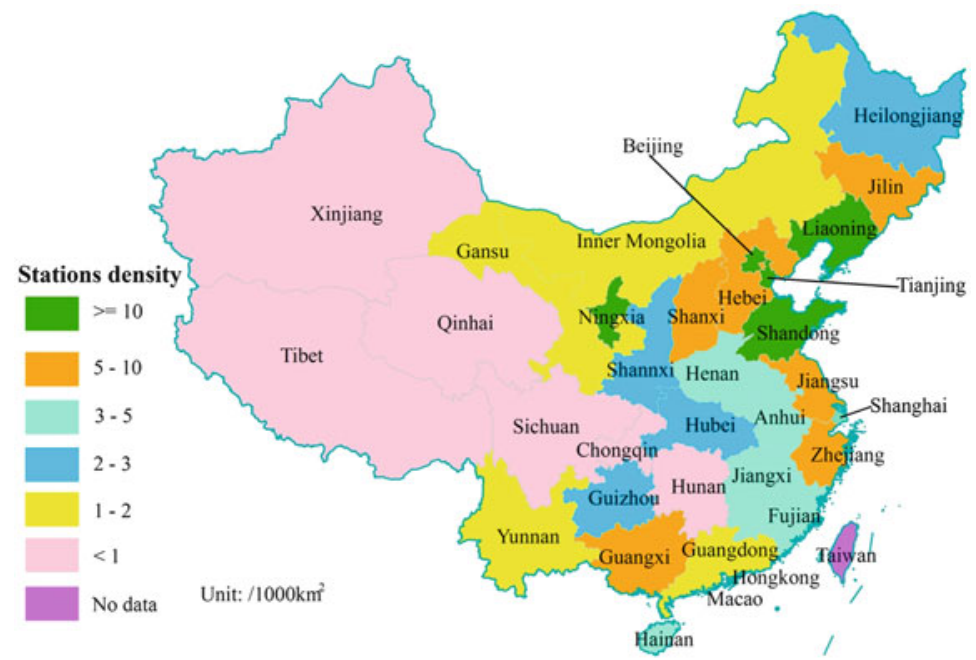

Fig. 18.6 National groundwater monitoring network in China (Data Source: China Institute of Geo-Environment Monitoring)

Construction (now the Ministry of Housing and Urban-rural Development) and the Ministry of Land and Resources have been moved to the Ministry of Water Resources. The Water Law was amended in 2002 to further strengthen the MWR's administrative power over groundwater. In 2011, the Plan of Groundwater Pollution Control and Remediation was issued, which was a joint effort of the Ministry of Environmental Protection, the Ministry of Water Resources, the Ministry of Land and Resources and the Ministry of Housing and Urban-rural Development. In 2012, the Land Subsidence Control Program (2011-2020) was launched by the Ministry of Land and Resources and the Ministry of Water Resources. Following those, the Working Plan of Groundwater Pollution Control and Remediation in the North China Plain was issued in 2013, which was also a joint effort by the Ministry of Environmental Protection, the Ministry of Water Resources, the Ministry of Land and Resources and the Ministry of Housing and Urban-rural Development. Integrated considerations of surface water and groundwater, water quantity and quality, groundwater exploitation and its subsequent consequences were reflected to some extent in the various programs mentioned above.

\subsection{Analysis of the Integration in China's Groundwater Management}

Although groundwater development and management in China has made great strides in the past decades, the outlook for groundwater management is still not optimistic. In major pumping areas like the North China Plain, groundwater 
overdraft is still severe. The average water table decline rate from 1980 to 1985 was about $0.5 \mathrm{~m} /$ year, slowed down in 1986-1995, but increased to more than $0.5 \mathrm{~m} /$ year from 1996 to 2008. The average annual groundwater storage depletion for the NCP is approximately 4 billion $\mathrm{m}^{3}$ (Cao et al. 2013). The overdraft of groundwater caused further eco-environmental problems, such as land subsidence, sea water intrusion and groundwater quality deterioration. Based on groundwater sampling in the NCP by the China Geological Survey, $58 \%$ of the samples showed poor quality (category IV or V). Land areas subsiding more than $200 \mathrm{~mm}$ extended $60,000 \mathrm{~km}^{2}$, with the estimated economic loss at about 330 billion RMB.

The major challenges of integration in groundwater management come from both the defining characteristics of groundwater itself and the particular social, cultural and political contexts of China. Groundwater, by its very nature, has multifunctional characteristics: it is an important part of the hydrologic cycle and important resource; at the same time it occurs in geological media and is also a type of mineral resource. In addition, groundwater has environmental values, the quality of which significantly affects human health and ecosystems. As a commonpool resource, groundwater is easily appropriated simply by capturing it, and the negative externalities associated with its use as well as the difficulty to measure this invisible resource add to the complexity of groundwater management (Wijnen et al. 2012). Cooperation among users is promoted as a means of achieving better management, internalizing the damages of users' activities and reducing extractions (Esteban and Dinar 2011).

Through this historical review of groundwater development and management in China, it can be seen that "integration" has been gradually taking place in the nation's groundwater policies due to the increasing intensity of groundwater exploitation and its subsequent problems. The integration dimension has been reflected in the legal framework and the changes of the institutional system in charge of groundwater management, but challenges still exist.

\subsubsection{Integration of Groundwater Quantity, Quality and Dependent Ecosystems}

In the initial phase of groundwater development, the major task facing China was to identify groundwater sources by conducting hydrogeological investigations. With the fast exploitation of groundwater in the 1960s-1980s for agricultural activities and economic development, groundwater-related geo-environmental issues started to emerge. The land subsidence in Shanghai started from the 1960s, and initiated the concerns over environmental issues caused by groundwater overdraft. Environmental Geology became a major field of research and practice at that time aimed at the protection of groundwater from water table decline, quality deterioration, land subsidence and collapses, and seawater intrusion. In addition, changes in groundwater quantity and quality can adversely impact many ecosystems in China that rely on groundwater to survive. 
Although the concerns over groundwater related environmental issues started in the 1960s, most of the work that has been done is scientific research in nature and has not been explicitly reflected in laws or regulations. In 2011, the State Council issued the National Plan for Groundwater Pollution Prevention and Control (2011-2020), which became an important official directive for groundwater quality management; in 2012, the National Plan for Land Subsidence Prevention and Control (2011-2020) was issued by the Ministry of Land and Resources and the Ministry of Water Resources, providing the official guidelines for the management of land subsidence. In this Plan, it is required to strictly restrict groundwater overdraft by controlling total groundwater pumping amount and the groundwater level. A water resources evaluation system is required if construction projects such as city construction and mining need to pump groundwater. The areas to limit or prohibit groundwater pumping need to be delineated. Based on the requirement of land subsidence control of a specific area, the goal of groundwater pumping control and reduction should be determined. At the same time, the construction of substitute water sources should be expedited to guarantee the requirement of domestic and industrial water uses.

In 2013, the Working Plan of Groundwater Pollution Prevention and Control in the North China Plain was issued to make specific provisions of groundwater protection in the NCP as a pilot study, and the Ministry of Environmental Protection, Ministry of Land and Resources, Ministry of Housing and Urban-rural Development, and Ministry of Water Resources were all involved. The working plan mandates that MEP constructs the monitoring network of groundwater quality and organizes routine groundwater quality monitoring, which should be linked up with the" National Groundwater Monitoring Project" implemented by the MLR and the MWR with all obtained information shared. The working plan is closely linked with the existing plans of water pollution prevention and control in the Haihe River Basin, the Yellow River Basin and other large river basins to manage surface water and groundwater quality jointly. The management of waste water outlets to rivers/ lakes, water permits and environmental evaluation should be coordinated. The plan also mentions that the coordination of the relevant laws and regulations of groundwater pollution prevention and control should be enhanced, and that groundwater quality standards should be formulated and linked with the Standards for Drinking Water Quality. The enactment of regulations about the responsibility and compensation of groundwater contamination should be speeded up. Sound and diversified funding and financing mechanisms for groundwater remediation should be constructed with stakeholders, local and central government all involved. The responsibility of stakeholders and local governments is strengthened, and the executive leadership responsibility system is implemented, and therefore the groundwater pollution prevention and control is brought into the planning of local social and economic development. The MEP coordinates and supervises the implementation of the Working Plan in coordination with other relevant organizations such as the MLR, National Development and Reform Commission, Ministry of Finance, Ministry of Housing and Urban-rural Development, and the MWR. 


\subsubsection{Integration of Surface Water and Groundwater}

"Integration of surface water and groundwater use" is explicitly mentioned in the Water Law, with the understanding that they are one single resource of the hydrologic cycle, but there are no specific and detailed regulations on how to integrate them. Most of the work related to integration of surface water and groundwater remains mainly at the technical level, such as characterizing the spatial and temporal connection of the major river-aquifer systems, and development of generic approaches/tools to identify and quantify the nature and extent of interaction between the surface and groundwater (Liu et al. 2014; Huang et al. 2012). However, the policy challenges have rarely been addressed; for example, how to integrate extraction limits in highly connected river-aquifer systems, and how to address groundwater extraction to meet environmental flow requirements of rivers. Substantial technical investigation and policy development are still needed towards integrated groundwater and surface water management.

Managed aquifer recharge (MAR) is one of the methods to integrate surface water and groundwater (see Chaps. 16 and 17). MAR uses excess runoff or reused urban waste water to recharge aquifers and offsets the decreased recharge that has been caused by reservoir construction or overdraft of groundwater. China has a long history in managed aquifer recharge. Dating back to the Qing Dynasty (1644-1911), people in the Huantai County of Shandong Province excavated subsurface channel-wells along the Wuhe River and used river water to recharge groundwater. Since the 1960s, cooling water and tap water were used to recharge groundwater to recover groundwater level in Shanghai as well as to prevent and control land subsidence. Before the 1990s the well-channel irrigation system was popularized in northern rural China with a combination of groundwater exploitation and recharge. In the 1990s, lots of facilities, such as underground reservoirs in coastal areas, were built to prevent sea water intrusion by groundwater recharge with surplus floods (Wang et al. 2010b). In the North China Plain, Xu et al. (2009) identified specific regions that could be targeted for MAR, all of which are alluvial fans in the piedmont of the Taihang Mountains, where regional recharge occurs (Currell et al. 2012). The South-to-North Water Transfer project has been under construction to transfer a billion cubic meters of surface water from southern China to northern China which is plagued by groundwater overdraft. This would be a good example to use surface water and groundwater conjunctively over a large spatial scale. With the transferred surface water satisfying parts of the water demands, groundwater can be conserved and protected to some extent.

\subsubsection{Incompleteness of Legal Framework}

The incompleteness in the current legal framework in China has limited the implementation of integrated groundwater management. Article 12 in the Water Law (issued in 1988 and amended in 2002) regulates the administrative system of water resources, which is to integrate watershed management with the management 
of administrative regions. The department of water administration under the State Council, that is, Ministry of Water Resources (MWR), is in charge of the integrated administration and supervision of water resources throughout the country. MWR establishes watershed management organizations for the major rivers and lakes, which perform the managing and supervising duties in their jurisdiction. The department of water administration under the local governments at or above the county level is responsible for the integrated management and supervision within their respective administrative regions.

Water planning is listed as an independent chapter (Article 14-19) in the Water Law to emphasize the importance of planning and its legal status. It is emphasized that integrated water planning should be done based on watersheds and regions, with the regional planning complying with watershed planning, and professional planning (such as flood control, irrigation, shipping, water supply, hydropower generation, and fisheries) complying with integrated planning (the overall arrangements of water exploitation, utilization, conservation and protection). The planning should be based on a comprehensive scientific survey and an investigation and assessment co-organized by the department of water administration at or above the county level in conjunction with the relevant departments at the same level.

Article 23 indicates that local governments at different levels should utilize surface water and groundwater conjunctively and make a rational and integrated exploitation of water based on the actual conditions of the local water resources. Article 36 mentions that groundwater abstraction should be strictly controlled in overdraft areas by the local government at and above county level. Scientific studies should be conducted and measures adopted if pumping groundwater in coastal areas in order to prevent land subsidence and sea water intrusion.

Although the Water Law has explicitly mentioned the "integration" issue in several of its articles, the legal regime is still far from complete and fails to capture important issues such as the necessity for integrated management and control of water quantity and quality. Article 32 mentions that the departments of water administration at or above the county level or watershed management organizations should evaluate the pollutant carrying capacity of a certain watershed and then provide suggestions of the total pollution discharge to the administrative department of environmental protection. The departments of water administration at or above the county level or watershed management organizations undertake the water quality monitoring task, and need to report to the administrative department of environmental protection. This segmentation in managing water quantity and quality will inevitably hinder the realization of integrated groundwater management.

\subsubsection{Defective Institutional System}

An integrated institutional system that is a good fit for the characteristics of groundwater resources has not been established in China. A coordinating organization is lacking and both segmentation and overlapping exist in the function of the 
major water management departments. Even though the amended Water Law indicates that the MWR has the right to govern water resources in an integrated fashion, including the protection and management of water resources, there is no further definition of what exactly the department is in charge of in the law. The multi-sectoral management system has caused undue overlaps, conflict of interests and additional complexity in solving problems (Department of Water Resources Management 2008). The Ministry of Land and Resources and its subordinate units take on the basic hydrogeological survey tasks and gather the basic geological data and information. In the meantime, the administrative function of groundwater management belongs to the Ministry of Water Resources, which is in charge of issuing groundwater abstraction permits and owns the information on groundwater utilization. The groundwater quality and pollution issue is under the jurisdiction of the Ministry of Environmental Protection. This has caused significant difficulties in data sharing and use, and prevented the hydrogeological surveys and groundwater contamination assessment to achieve the best outcomes.

Although watershed management organizations have been constructed and their legal status has been defined in the amended Water Law, the actual situation is that the management power of watershed management organizations is very limited. At present the major tasks of the watershed management organizations center on construction and management of river flood control systems and development of some ad hoc projects at the watershed scale, but they do not play a substantive role in the development and management of water resources, especially groundwater resources, at the watershed scale.

The current situation of water management authority has left "policy implementation ... fragmented and disjointed" (Foster et al. 2004). Many local governments have been slow to embrace the laws and regulations; as a result enforcement of the laws varies widely among the localities. In addition, as an institutional setting, each administrative division has its own water resource management departments. A local bureau only reports to its corresponding local government, not the bureaus or ministry above it. A higher bureau has no mandatory power over the lower one (the broken arrows in Fig. 18.7 showing the indirect leadership). Furthermore, a bureau is financially supported by the local government whose budget mostly depends on its local GDP. All these tend to promote local protectionism which affects policy implementation, and also breaks the integrity and integration of watershed management (Saleth and Dinar 2000).

\subsubsection{Lack of Information Sharing and Public Participation}

As a public resource, groundwater governance cannot continue without public participation. In western countries such as the European Union and Australia, the system of public participation is specified in legal documents, and the public plays an important role in groundwater protection. In the United States, since the "Love Canal" incident and largely spurred by it, citizen groups have demanded more inclusion in decision processes that affect their communities, such as the cleanup of 


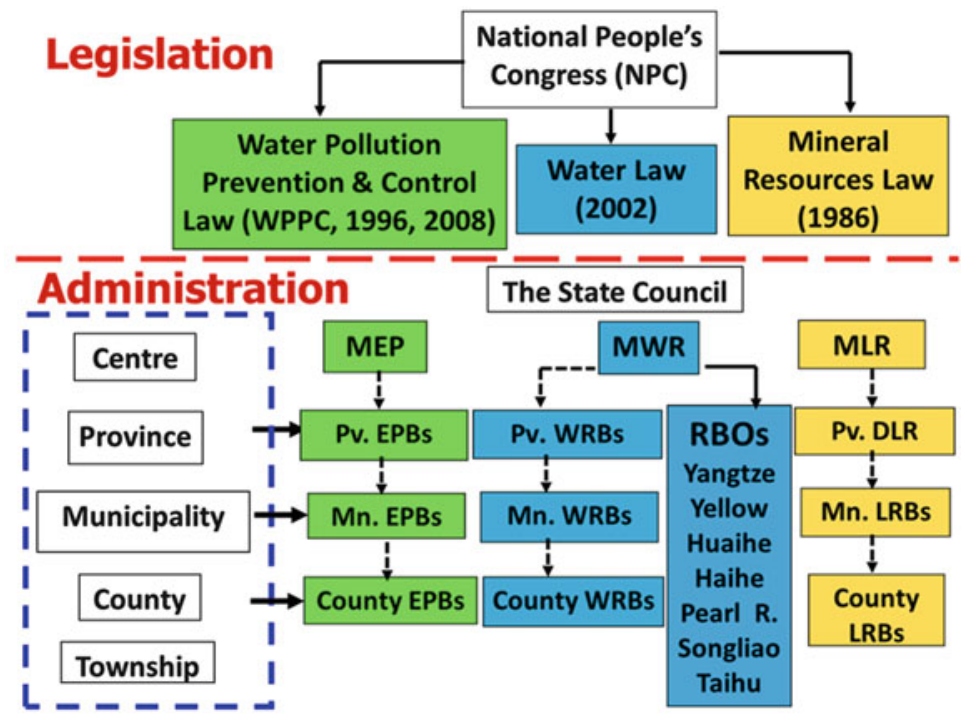

Fig. 18.7 Legislation, administrational and institutional system of groundwater management in China (Acronyms: $M W R$ Ministry of Water Resources, MEP Ministry of Environmental Protection, MLR Ministry of Land and Resources, WRB Water Resources Bureau, EPB Environmental Protection Bureau, DLR Department of Land and Resources, $L R B$ Land and Resources Bureau, $R B O$ River Basin Organizations)

The solid arrows depict the political dependency

The broken arrows indicate indirect leadership - mainly professional guidance from higher-level authorities without any hierarchical subordination

Superfund sites. But in China the public participation system has not been defined in current groundwater-related laws and regulations. Public awareness of the importance of groundwater and the status of groundwater quantity and quality is lacking. One prerequisite for public participation is to have a transparent institutional structure and accessible information (Winalski 2009). Data publishing and information sharing should be promoted; education of the public regarding groundwater protection is needed. "Any law lacks teeth unless public involvement fostered by education and media coverage promotes and accelerates the implementation process as an external factor" (Beyer 2006).

\subsection{Recommendations Towards More Integrated Groundwater Management in China}

China's State Council warned in 2007 that by 2030 China's water use will reach or approach the total volume of exploitable water resources. The country will consume 750 billion $\mathrm{m}^{3}$ of water per year by 2030 , about $90 \%$ of the total amount of usable water resources in the country (Qiu 2010). With changing climate and intensifying 
human activities, groundwater will continue to be used intensively in China, putting groundwater management under increasing stresses. The wide-ranging spatial and temporal scales of groundwater resources in China necessitate an integrated approach for exploitation and management. Implementing integrated groundwater management is a question of getting the "three pillars" right: (1) moving towards an enabling environment of appropriate legislation, policies and strategies; (2) putting in place the institutional framework through which policies can be implemented; and (3) setting up the management instruments required by these institutions to do their job (Water Partnership Program 2014). This has provided a general instruction for implementing integrated groundwater management in China.

Over the past 60 years, China has made great progress towards the integrated management of groundwater. However, there is still much work that needs to be done to continue the integration. Firstly, the legislation system should be improved. China still has no groundwater-specific laws and regulations, only with some provisions in general terms (the Water Law and the WPPC Law) regulating groundwater management. The overlapping of the WPPC Law and the Water Law leads to the confusion of institutional responsibilities of the MWR and the MEP as well as their local counterparts. In addition, the groundwater legal regime is far from complete and fails to capture important issues such as the necessity for integrated management and control of water quantity and quality. The formulation of specific "Groundwater Management Regulations" and the technical standards on groundwater development should be speeded up to enhance groundwater governance and protection in accordance with laws. The vague statutory language and general terms of the present laws and regulations also create obstacles to the implementation process, and need to be more clarified and specific.

Secondly, institutional reforms are needed to straighten out several critical relationships, including the relationship among different organizations with water-related jurisdiction, the relationship between the national and local governments, and the relationship between watershed based and administrative division based management approaches. The responsibilities, authorities and interests of each side should be clarified. Under the current institutional system, the management of water quantity and water quality is divided and is under the administration of the MWR and the MEP separately. A suggestion to resolve this separation is to construct an integrated water resources management system led by the MWR, and a supervision system on water environment protection led by the MEP. To improve watershed management, the relationship between watershed management organizations and the regional management authorities should be carefully defined. Different levels should be differentiated for the watershed management and regional management. In general, the institutional reforms involve the distribution of important resources and are closely related to the national political system. Information sharing and collaborations among those related organizations and at different levels are essential for integrated groundwater management.

Thirdly, it is urgently needed to set up the management instruments and build up professional management teams to guarantee the implementation of integrated groundwater management. Currently the MWR has led integrated water resources 
management, but for a long period the MWR has mainly managed surface water and lacks experience in managing groundwater. It is important to build up the capacity in managing groundwater, including the formation, distribution, transformation of groundwater and its interaction with surface water. A dynamic national groundwater monitoring network should be constructed with improved metering techniques to collect information and provide the scientific foundation for groundwater management. Data dissemination and access, and information sharing should also be greatly improved. In addition it is essential to improve participation of stakeholders and to enhance public awareness and education of groundwater utilization and problems.

Finally, China should rethink its economic development strategy, population policy, and food security policy. China has been attaching primary importance to the development of the economy in the past three decades. Environmental quality and ecosystem health have not been given sufficient consideration, although the situation has been improving recently. It is essential to integrate the eco-environmental factors into its sustainable development strategy. Agriculture is the largest groundwater consumer among the various water using sectors, and therefore how to optimize certain agricultural water use requirements without threatening the food security policy will be an important issue. With the population exceeding 1.3 billion, nearly $20 \%$ of the world's population, China is facing unprecedented challenges in managing its limited water resources. In general, to manage China's groundwater resources effectively and sustainably, various aspects discussed in this chapter must be considered, including philosophical, legal, scientific and technological. This is a long-term goal that needs continuous and relentless efforts.

Acknowledgements The authors greatly appreciate the valuable comments by Jean-Daniel Rinaudo and Randy Hunt which have led to significant improvement of the presentation. The support for this work was provided by the National Natural Science Foundation of China (No. 41271032 and No. 91225301).

Open Access This chapter is distributed under the terms of the Creative Commons AttributionNoncommercial 2.5 License (http://creativecommons.org/licenses/by-nc/2.5/) which permits any noncommercial use, distribution, and reproduction in any medium, provided the original author(s) and source are credited.

The images or other third party material in this chapter are included in the work's Creative Commons license, unless indicated otherwise in the credit line; if such material is not included in the work's Creative Commons license and the respective action is not permitted by statutory regulation, users will need to obtain permission from the license holder to duplicate, adapt or reproduce the material.

\section{References}

Barthel R, Jagelke J, Gotzinger J et al (2008) Aspects of choosing appropriate concepts for modeling groundwater resources in regional integrated water resources management examples from the Neckar (Germany) and Oueme catchment (Benin). Phys Chem Earth 33:92-114 
Beyer S (2006) Environmental law and policy in the people's Republic of China Chinese. JIL 5 (1):185-211

Cao G, Zheng C, Scanlon BR et al (2013) Use of flow modeling to assess sustainability of groundwater resources in the North China Plain. Water Resour Res 49:159-175. doi:10. 1029/2012WR011899

China Ministry of Environmental Protection (1994) National quality standard for ground water (GB/T 14848-93)

China's Groundwater Information Center (2014) http://www.cigem.gov.cn. Accessed 20 Apr 2014

Demetriou C, Punthakey JF (1999) Evaluating sustainable groundwater management options using the MIKE SHE integrated hydrogeological modeling package. Environ Model Software 14:129-140

Department of Water Resources Management, the Ministry of Water Resources (2008) The collection of groundwater laws, regulations and standards. China Standard Press (in Chinese), Beijing

Esteban E, Dinar A (2011) Collective action and the commons: are cooperative groundwater institutions stable in the presence of environmental externalities? Water Science and Policy Center, Riverside

Foster S, Garduno H, Evans R et al (2004) Quaternary aquifer of the North China Plain - assessing and achieving groundwater resource sustainability. Hydrogeol J 12:81-93

Han D, Chen Z et al (2012) Sustainability of groundwater usage in northern China: dependence on palaeowaters and effects on water quality, quantity and ecosystem health. Hydrol Process. doi:10.1002/hyp. 9208

Huang L, Zheng C, Liu J et al (2012) Application of distributed temperature sensing to study groundwater-surface water interactions in the Heihe river basin. Hydrogeol Eng Geol 39(2):611 (in Chinese)

Ji C, Wang Z (2009) Sixty years retrospect and prospect of China's hydrogeology and engineering geology. Paper presented at the 21st conference of committee of geological history, geological society of China, China University of Geosciences (Beijing), Beijing, Oct 2009

Liu Z (1987) Introduction of groundwater utilization in ancient China. Ground Water 3:186-187 (in Chinese)

Liu C, Yu J, Kendy E (2001) Groundwater exploitation and its impact on the environment in the North China Plain. Water Int 36(2):265-272

Liu J, Zheng C, Zheng L et al (2008) Ground water sustainability: methodology and application to the North China Plain. Ground Water 46:897-909

Liu C, Hu Y, Liu J et al (2014) Advances in the use of temperature data for study of surface watergroundwater interactions. Hydrogeol Eng Geol 41(5):5-10

Ministry of Environment Protection (2011) National pollution groundwater prevention plan (2011-2020). Index No. 000014672/2015-00539

Ministry of Environmental Protection (2012) China's Environmental Bulletin. Index No. 000014672/2015-00539

Ministry of Water Resources (2011) China Water Resources Bulletin (1997-2011). China Water Power Press, Beijing. ISBN 7508490797, 9787508490793

Qin H, Cao G, Kristensen M et al (2013) Integrated hydrological modeling of the North China Plain and implications for sustainable water management. Hydrol Earth Syst Sci 17:3759-3778

Qiu J (2010) China faces up to groundwater crisis. Nature 466:308

Qiu J (2011) China to spend billions cleaning up groundwater. Science 334:11

Saleth R, Dinar A (2000) Institutional changes in global water sector: trends, patterns, and implications. Water Policy 2:175-199

Shu Y, Villholth K, Jensen K et al (2012) Integrated hydrological modeling of the North China Plain: options for sustainable groundwater use in the alluvial plain of Mt. Taihang. J Hydrol 464-465:79-93

Tang K, Wu Y, Hou J (2006) Assessment of groundwater quality in China: groundwater quality and pollution analysis. Water Resour Prot 22(3):1-4 (in Chinese) 
Wang J, Huang J, Zhang L et al (2010a) Water governance and water use efficiency: the five principles of WUA management and performance in China. J Am Water Resour Assoc 46(4): $665-685$

Wang W, Sun X, Xu Y (2010b) Recent advances in managed aquifer recharge in China. 2010. In: International conference on challenges in environmental science and computer engineering, vol 2, pp 516-519. doi:10.1109/CESCE.2010.100

Water Partnership Program (2014) www.gwpforum.org. Accessed 20 Apr 2014

Wijnen M, Augeard B, Hiller B et al (2012) Managing the invisible - understanding and improving groundwater governance. Water Partnership Program. http://water.worldbank.org/sites/water. worldbank.org/files/publication/ESW_Managing-the-invisible.pdf. Accessed 20 Apr 2014

Winalski D (2009) Cleaner water in China? The implications of the amendments to China's law on the prevention and control of water pollution. J Environ Law Litig 24:181-202

Xu G, Liu L, Fei Y et al (2009) Research on the adjustment of groundwater storage in the North China Plain. Resour Sci 31:375-381 (in Chinese)

Yang H, Zehnder A (2007) "Virtual water": an unfolding concept in integrated water resources management. Water Resour Res 43:W12301. doi:10.1029/2007WR006048

Zhang Z, Li L (eds) (2004) Groundwater resources of China. SinoMaps Press, Beijing. ISBN 7-5031-3418-6

Zhang L, Wang J, Huang J et al (2008) Development of groundwater markets in China: a glimpse into progress to date. World Dev 36(4):706-726

Zhang Z, Fei Y, Guo C et al (2012) Regional groundwater contamination assessment in the North China Plain. J Jilin Univ (Earth Sci Ed) 42(5):1456-1461

Zheng C, Liu J (2013) China's "Love Canal" moment? Science 340:810

Zheng C, Liu J, Cao G et al (2010) Can China cope with its water crisis? - perspectives from the North China Plain. Ground Water 48(3):350-354

Zhou Y, Dong D, Liu J et al (2013) Upgrading a regional groundwater level monitoring network for Beijing Plain, China. Geosci Front 4:127-138 